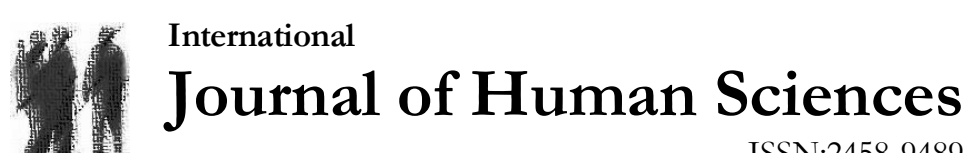 \\ ISSN:2458-9489
}

Volume 15 Issue 4 Year: 2018

\section{An evaluation of urban open spaces in Historical City Center of Konya in the context of pedestrian mobility}

\author{
Bilgehan Yilmaz Çakmak ${ }^{1}$ \\ Mehmet Topçu ${ }^{2}$
}

\begin{abstract}
Cities are organisms that live in a balance of continuity with the structures they possess and the urban open spaces that connect them. For this organism, staying alive and healthy is possible if urban dwellers, who are the users, utilize the spaces in a manner that preserves their integrity and locate each space in mental perception. Research problem/aim; Squares, which are one of the urban open spaces, are the breathing centers of the city that play important roles in maintaining this integrity. This study aims to test the relation of squares and pedestrian movement for each square and for the whole historical city. Method; In the present study examining the squares and their relationships in the historical city center of Konya province, 7 squares that have a semantic relationship resulting from being located on a specific axis with one another were analyzed with respect to pedestrian use and the respective physical characteristics of the squares. The main criteria defined in the study constitute the 3 steps of the method. These were identified as function-diversity, accessibility-form and livability-identity. Analyses were conducted based on the 3 established criteria and the 7 sub-criteria that measure the relationships among these at certain levels. Each analysis constitutes a step of the method and enables to achieve a result by using different measurement techniques. In the context of the analyses and findings, qualitative and quantitative studies such as a questionnaire study, land use, dominant land use, function diversity, global and local accessibility, form and geometry, urban open space and symbolic elements analyses were conducted for each square. Findings, Conclusions; As a result of this study carried out with the aim of reinforcing urban continuity and enhancing the relationship among squares, the primary data for each square were obtained and suggestions were presented for eliminating the deficiencies. With the implementation of these suggestions, the holistic perception of the squares, which are focal points located within the historical city center, will be stronger and these squares will have more enhanced functional and semantic connections with one another. In this way, significant contributions will be made regarding the users' getting to know the city center, the use of squares for different needs and the protection of the integrity of the historical city center with regard to cultural identity.
\end{abstract}

Keywords: Urban open space; space syntax; pedestrian mobility; continuity; squares; Konya.

\footnotetext{
1 Assist. Prof. Dr., Konya Technic University, Faculty of Architecture and Design, Architectural Department, cakmakbilgehan@gmail.com (corresponding author)

2 Assoc. Prof. Dr., Konya Technic University, Faculty of Architecture and Design, City and Regional Planning Department, mehmetopcu@gmail.com
} 
Yılmaz Çakmak, B., Topçu, M., (2018). An evaluation of urban open spaces in Historical City Center of Konya in the context of pedestrian mobility.Journal of Human Sciences, 15(1), 1827-1846. doi:10.14687/jhs.v15i4.5506

\section{Introduction}

Cities are living and acting organisms which are composed of public and private structures and urban open spaces that interconnect these structures. In addition to defining urban open spaces as the spaces existing among structures, they should also be defined as spaces that connect sites, give meaning to the city with the balance between fullness and emptiness and contribute to the formation of urban identity through their unique functions. When defining the city, Gordon Cullen portrays it as a world of black and white. In this world, the roads are for movement and relationships, and the buildings are for social and business purposes. The place out-of-doors is utilized for social and business purposes (Cullen, 1961).

When we examine the use of urban open spaces from past to present, we see that a change has been experienced from the boundary elements that create the space to the functions that serve the open space, and this change has led to unidentifiability. This unidentifiability decreases the importance and efficiency of urban open spaces, causes uncertainties in the legibility of cities and urban identity.

In the current literature, as important elements of urban open spaces, squares are defined as urban spaces in which various activities are performed, pedestrian movement is maintained, and which are supported by limiting and defining elements. In this context, squares are not only points for gathering, resting and relaxation, but are also areas that maintain urban integrity and where urban identity is perceived.

In this paper, urban open spaces that are located in the historical city center and have strong and weak functional and contextual relationships with one another are quantitatively and qualitatively analyzed with exclusive focus on squares. These analyses aim to identify space use, pedestrian movements, pedestrian behavior and preferences, accessibility, morphological structure and integration of space with the environment. The analyses are supported with the movement tracks of the users in the squares and the present data are compared with the usage data. On the identified route, the relationship of the open spaces with the city and among one another is examined for improving the state of connectedness and continuity. In addition, the contributions of continuity to urban identity and perception are also investigated.

\section{Conceptual Framework}

\section{The Concept of Urban Open Space}

An urban open space network, which forms the backbone of the fabric and maintains vehicle-pedestrian circulation, is the most important factor determining the fabric typology. This network system, which is formed through the end-to-end connection of the volumes outside the buildings, constitute the basic configuration of an urban fabric through the morphological clustering of point (gathering - dispersing and activity spaces) and linear (passage spaces) space elements (Kürkçüoğlu \& Ocakçı, 2015). Point spaces can be exemplified as squares, nodes, transfer points, parks, and playgrounds; while alleys, streets, boulevards, passages, stair alleys and walkways can be examples for linear spaces. Point and linear spaces that constitute the urban open space network are also among the "image elements of urban space" defined by Lynch (1960). Point spaces are identified as junctions and nodes that constitute the symbolic spots of the city and enrich the urban image, whereas linear spaces are defined as paths that enable the circulation within the city and connect the sub-regions or points to one another (Kürkçüoğlu, 2015).

Although discussed in different ways by several approaches, space or place in a broader sense is defined as an emptiness that separates the human from the environment to a certain extent and which is suitable for the human to continue their actions within it and the piece of space whose edges can be perceived by the observer(s). Architectural space is the piece of space or special emptiness which is horizontally and vertically separated through visible or invisible borders from the infinite space, which is difficult to grasp and perceive. 
Yllmaz Çakmak, B., Topçu, M., (2018). An evaluation of urban open spaces in Historical City Center of Konya in the context of pedestrian mobility.Journal of Human Sciences, 15(1), 1827-1846. doi:10.14687/jhs.v15i4.5506

As it is understood from the definition of space given by Francis D.K. Ching as "Space constantly encompasses our being. Through the volume of space, we move, see forms, hear sounds, feel breezes, smell the fragrances of a flower garden in bloom. It is a material substance like wood or stone. Yet it is an inherently formless vapor. Its visual form, its dimensions and scale, the quality of its light-all of these qualities depend on our perception of the spatial boundaries defined by elements of form. As space begins to be captured, molded, and organized by the elements of mass, architecture comes into being." the existence of space is maintained through the perception of a volume of space by our senses in the context of continuity and mobility. Space gains meaning as long as this existence is supported by light, sound, scale, harmony and unity principles (Ching, 2014).

For space, the state of being closed, semi-open or open varies from micro to macro scale at various dimensions and levels. Different types of spaces that exist within this variation continuously change and develop in accordance with the needs and actions of the human and are redesigned based on different styles of perception. In this context, the existence of architectural and urban space is possible through the movement of the human who perceives and functionally utilizes it within that space.

In this context, it is necessary to evaluate urban open spaces socially and culturally in terms of the perception levels, views and social expectations of the users that move within them, and also physically in terms of their accessibility, legibility, and functional values. At this point, the topic needs to be addressed within the context of urban open space design criteria to be able to perform a universal evaluation.

\section{Design Criteria in Urban Open Spaces}

Urban open spaces are areas that maintain the urban balance between fullness-emptiness, meaning-integrity and functionality- aesthetics in the $2^{\text {nd }}$ and $3^{\text {rd }}$ dimensions. From this point of view, they need to exist in an order and organization within the urban whole. The design criteria of urban open spaces can be interpreted under three main topics (Francis, 1987; Korkmaz, 2001; Southworth, 1989). These are;

\section{- Function - Diversity}

- Accessibility - Form

- Livability - Identity

Among these concepts, the notion of function embodies the criteria such as the presentation of the functions existing in the space to all users under equal conditions, the organization of public transportation systems and the maintenance of a balanced distribution of the existing activities. The diversity of functions also has an important place among the design criteria of urban open spaces (Francis, 1987). This is because the contemporary understanding of design looks for diversity in the space, and enables cultural enrichment by bringing together individuals of different cultural, historical and artistic backgrounds. Socioeconomic environment emerges as an important criterion in the design of urban open spaces. Maintenance of a quality social life can be evaluated in terms of control and participation, equality and liveliness. User participation is an important step in maintaining the active use of the space in the design of open spaces. User participation is necessary for determining the functions to be provided in the space and maintaining the variety of actions. A quality urban open space can be established based on an inquiry on the hours of use in the day, the frequency of use and for what purposes the area is used. In addition, it is necessary to ensure the equal use of all facilities by all urban dwellers and enable diversity with an egalitarian approach. The urban open space should offer variety also with its night and daytime use.

In terms of form (shape and aesthetics) the design of urban open spaces requires attention to the differences in the preferences and behavior of individuals from different socioeconomic levels that result from their different levels of perception. The basic factors that affect perception can be grouped into three as user characteristics, user behavior in the urban space and space characteristics. The characteristics of the space constitute the third group which affects perception. 
Yllmaz Çakmak, B., Topçu, M., (2018). An evaluation of urban open spaces in Historical City Center of Konya in the context of pedestrian mobility.Journal of Human Sciences, 15(1), 1827-1846. doi:10.14687/jhs.v15i4.5506

These characteristics embrace the elements that form the space such as the dimensions of the space elements, materials, mobility in the fronts, direction, continuity, and density of straights, having diversity or similarity as well as environmental effects (Giritlioglu, 1991). For this reason, it would be appropriate to suggest solutions that meet the expectations of each individual and give importance to the design of open spaces for urban aesthetics. The form of the space should be in a way that enables the most efficient use with the functions it includes. In geometries close to basic geometry, shared spaces and pedestrian axes are worked out more functionally. The accessibility of urban open spaces within the urban whole and their state of accessibility for the surrounding area is important for the design and use of the space.

The criteria that constitute the notion of livability are comfort, safety and maintenance. While sitting elements, shaded and sunny areas, wind, rain and climatic arrangements maintain the criteria of comfort, areas separated from traffic and public transport arrangements maintain the criteria of safety. The regular control and maintenance of all these arrangements, urban furniture and recreation systems implements the criteria of maintenance. The applications such as urban furniture, lighting elements, signboards and direction signs, and ground textures in the space should be identified to determine the criterion of livability (Korkmaz, 2001; Southworth, 1989).

The criterion of 'identity' should be evaluated in terms of legibility and meaning. The legibility of urban open spaces is related to the perceptibility of the space by its users and its meaning to individuals (Southworth, 1989).

As points of reference, open spaces are important for the perception of the urban whole and in terms of acting as a guide for direction finding. The cultural and historical marks that urban memory leaves in the minds of individuals should be legible and visible in urban open spaces.

\section{Square as an Urban Open Space}

The concept of urban open space refers to urban spaces that exist outside of structures and buildings and serve certain functions. Sidewalks, vehicle stops, parks and recreation areas, car parks, vehicle and pedestrian roads and squares are elements that constitute urban open spaces. The concept of square, which is an important part of urban open spaces, will be illustrated in the study.

Squares are the most commonly and actively used element of urban open spaces. Squares are public spaces that are used by urbanites for general and specific purposes. Today, urban spaces fall under the pressure of the economic rationality in design, and spaces of similar character which lack identity and quality emerge as the urban image (square, street, yard, human scale, etc. as elements that define the city), and the urban culture (urbanity, awareness of being urbanite, values experienced in the city, traditions, customs,... ) of the Anatolian cities of the past are forgotten (Özer \& Ayten, 2005).

The most important function of squares is to create a social life (fabric) in the midst of buildings. Through the coexistence of more than one person in a public space, this social life enables individuals to communicate and socialize with each other, and creates a common identity. From the past to the present, squares have been meeting places for the townspeople or visitors, sites where they could take a breath to break away from the chaos of the city, find an opportunity to relax and rest, watch each other and share the events occur in the city, in short, multipurpose areas for use (Erdönmez \& Apak, 2015).

Schulz defines the square as "the most distinct and remarkable element of the urban structure", and states that "As a clearly delimited place it is most easily imaginable, and represents a goal for movement" (Norberg-Schulz, 1971).

\section{Formation of Square in the Historical Process}

Squares, which have been a part of urban open spaces and at the same time public spaces in the period from the past to the present, have been named based on a certain function or a structure they contain; Market Square, Fountain Square, Pier Square, Government Square, etc.

In the historical process, squares were viewed as the most prestigious places of the city as areas where common life existed consciously and in an organized way. Ceremonies, celebrations, festivals, shows were generally held in squares, but squares failed to meet the needs of the urbanites 
Yllmaz Çakmak, B., Topçu, M., (2018). An evaluation of urban open spaces in Historical City Center of Konya in the context of pedestrian mobility.Journal of Human Sciences, 15(1), 1827-1846. doi:10.14687/jhs.v15i4.5506

and started to lose their quality because of the fast urbanization that emerged with industrialization (Çubuk, 1991). In addition to losing the quality of being prestigious areas, another important loss for squares was their integration with transportation systems and vehicle roads. Squares suffer functional losses in areas where the vehicle-pedestrian relationship cannot be maintained in an organized way.

In developing cities, squares have started to lose their functional and visual qualities with the developing technology and transportation systems and at the same time the density of traffic caused by fast urbanization. All these developments caused squares to lose their essential functions and turn into spaces that serve vehicle traffic and throw pedestrian use out of focus (Kıliç, 2001).

\section{The Role of Squares in Urban Continuity and Sustainability}

The diversity and richness of the public spaces of a city, their publicness, accessibility, walkability and enabling the representation of different sections of the society makes that city and its public spaces livable and sustainable. Concerning the maintenance of urban sustainability, walkability makes the public space livable and dynamic; walkable spaces strengthen social life by mediating social interaction; contribute to the development of harmonious and livable communities (Akkar Ercen \& Belge, 2017).

As parts of urban open spaces, streets and squares are places where human mobility is observed, and which are organic parts of the city. The common point of the studies conducted on this topic is seen to be the certain significant qualities of squares such as being social production areas, meeting physical, perceptive and social needs and being accessible. With all these qualities, squares as urban spaces are of vital importance for sustainable cities with their psychosocial, spatial and ecological qualities (Eren, 2006).

When reviewing the sustainability of the squares in Turkey, one of the most important problems that emerge is the change observed in the form of social and spatial organization. The 'modern' urban design and planning studies which started with the Tanzimat reforms of the Ottoman period were in the form of formal 'transfers', and the lack of correspondence between the logic behind the creation of these new forms and the formation of the square on which they were built has constituted one of the most important sources of the problems that have existed up to the present time (Eren, 2006).

The urban open spaces, especially the squares in the historical city center in Konya have significant importance in the formation of urban identity in the context of urban continuity and the sustainability of squares. Squares are spaces where especially local and foreign tourists gain an impression regarding the urban whole and urban spirit. The behavior of the local people, local culture and lifestyle, socioeconomic structure and historical fabric are legible in the squares and cultural codes are transferred to future generations.

In this context, 7 squares from among the urban open spaces located in the Konya historical city center were selected as the study area and analyzed. The relationship of these squares among one another and with all urban spaces will be examined and suggestions will be offered regarding maintaining urban continuity.

\section{Method}

The squares selected as sampling area for the aim of maintaining the continuity of squares targeted within the scope of the study were examined based on the criteria determined within the theoretical framework. These criteria were identified as function-diversity, accessibility-form and livability-identity (Figure 1).

Within this scope, data were obtained for each criterion by using different measurement techniques. In analyzing the functional use of squares, frequency of use for each square was determined through a questionnaire study and function diversity was determined by means of land use analyses. Land use levels in the immediate environment of the squares were analyzed and dominant land use was determined in percentages. Afterwards, spatial accessibility values were calculated by using the space syntax method to determine the degree of spatial accessibility for the 
Yılmaz Çakmak, B., Topçu, M., (2018). An evaluation of urban open spaces in Historical City Center of Konya in the context of pedestrian mobility.Journal of Human Sciences, 15(1), 1827-1846. doi:10.14687/jhs.v15i4.5506

squares within the historical district. As to the criterion of form, the squares were assessed within the scope of determined geometric approaches. The criterion of livability was determined through urban open space analyses (urban furniture, landscape, lighting elements, ground covering materials, etc.) and on-site analyses for degree of use. The criterion of identity was quantitatively interpreted in the context of the monumental structures, symbolic elements and activities of memorial value around the squares in the historical district.

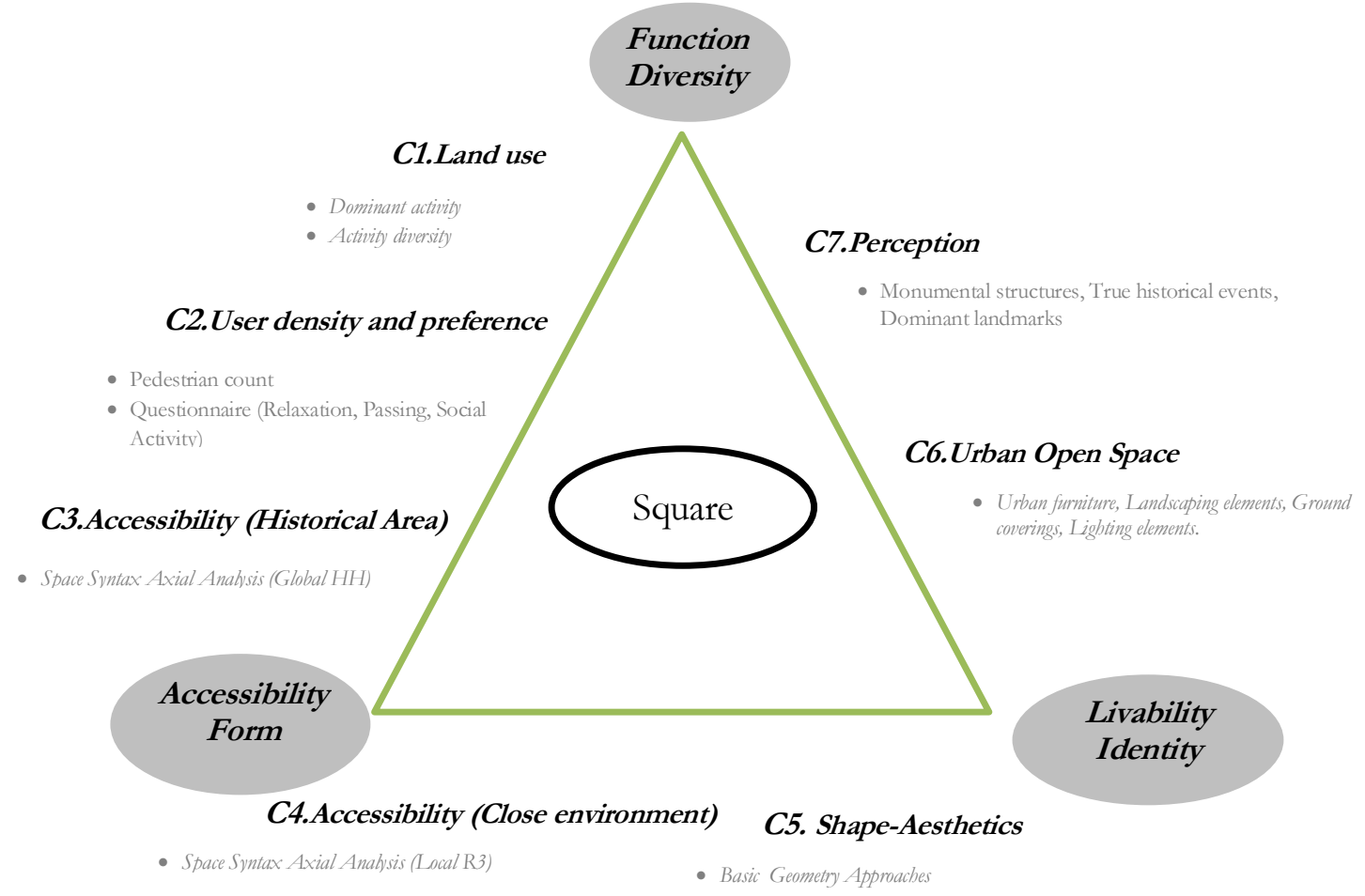

Figure 1. Evaluation criteria and method used in the study

\section{Field Study}

\section{Konya Historical City Center: Content and Fringes}

The part of Konya characterized as the traditional market and historical city center and where commercial, civil and historical buildings are concentrated is located within the town of Selçuklu to the east of Alaaddin Hill. A large part of the area consists of the historical city center, which developed and was used during the Seljuk period.

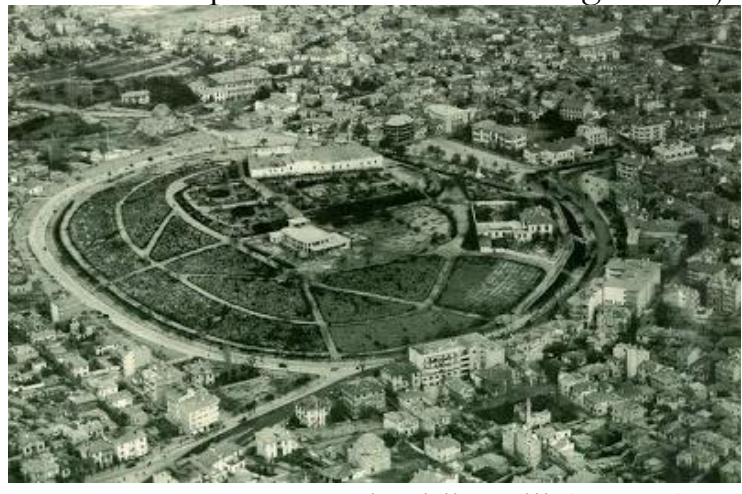

Figure 2. Konya Alaaddin Hill (URL 1)
Alaaddin Hill and its surroundings served as a hub which was used as the city center (or downtown) in the $15^{\text {th }}-16^{\text {th }}$ centuries. These areas included the main commercial spaces of the city in the Seljuk and Ottoman periods. When Konya was conquered, the city was located within the fortifications that surrounded the Alaaddin Hill. After the city walls were restored, a palace was built on the northern skirt of the hill, and Ulu Mosque (Alaaddin Mosque) was constructed in the middle of the hill (Figure 2).

In the study, Konya historical city center is described as the district bordered by the outer castle walls and its close surroundings. Within these borders, there is the Alaaddin hill and the 
Yılmaz Çakmak, B., Topçu, M., (2018). An evaluation of urban open spaces in Historical City Center of Konya in the context of pedestrian mobility.Journal of Human Sciences, 15(1), 1827-1846. doi:10.14687/jhs.v15i4.5506

vehicle axis surrounding it, historical buildings located on this axis and pedestrian and vehicle axes extending up to the Mevlana Museum (Figure 3).

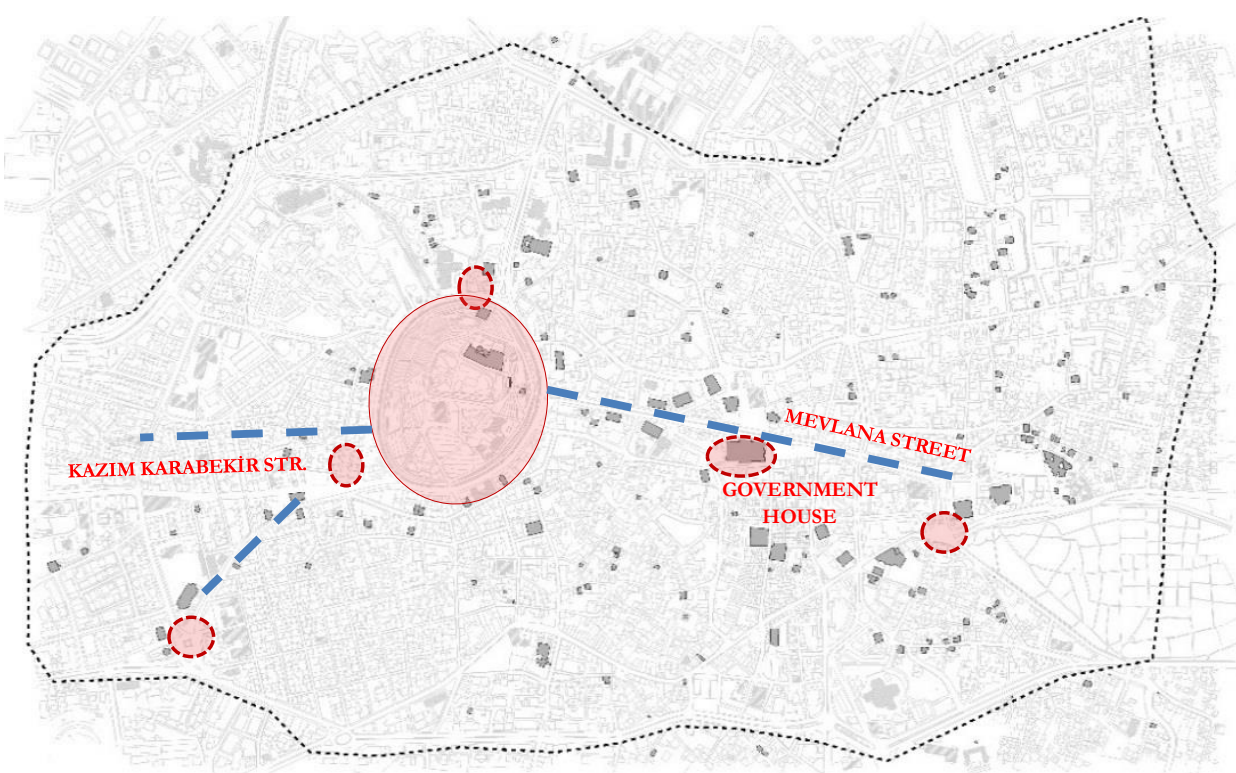

The urban open spaces (squares) located in the area defined as the historical city center, on Mevlana Street and around Alaaddin Hill were selected as the study area. Considering the significance of the historical city center in urban continuity, the role and importance of the selected area and squares becomes more evident. The axis on which the squares have been erected is the one located between the Alaaddin Hill and Mevlana Museum and important focal points such as the Government House and Şerafettin Mosque are connected to this axis (Figure 4).

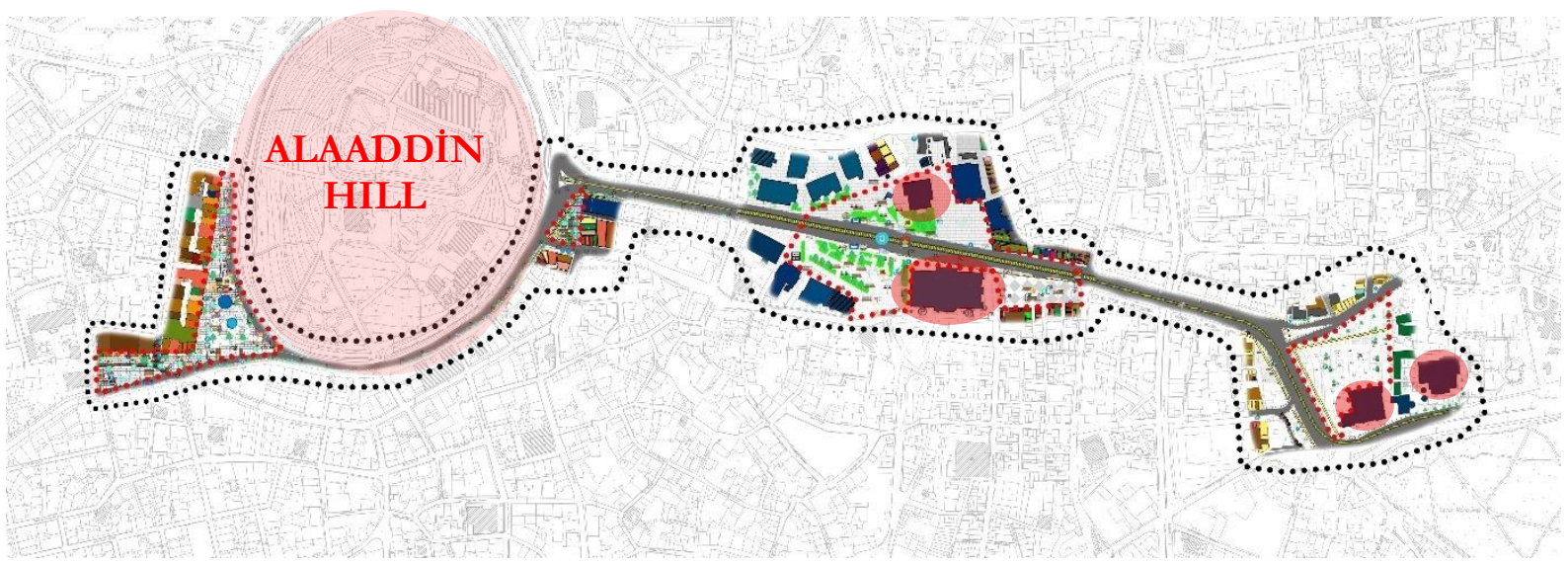

Figure 4. Edges of the Study Area

On the designated area, 7 different studies were conducted under 3 main topics in line with the urban open space design criteria and analyses and data collection for each square were performed within the scope of the determined method. These studies are as follows;

\section{C1. Land Use}

Land use analyses were carried out through determining the functions located in and around each square. The analyses were obtained by labeling the functions on the maps of the squares and showing the percentages on pie charts. Dominant activities and activity diversity were also presented in the same table (Table 1). 
Yılmaz Çakmak, B., Topçu, M., (2018). An evaluation of urban open spaces in Historical City Center of Konya in the context of pedestrian mobility.Journal of Human Sciences, 15(1), 1827-1846. doi:10.14687/jhs.v15i4.5506

Table 1. Land use, dominant land use and activity diversity analyses

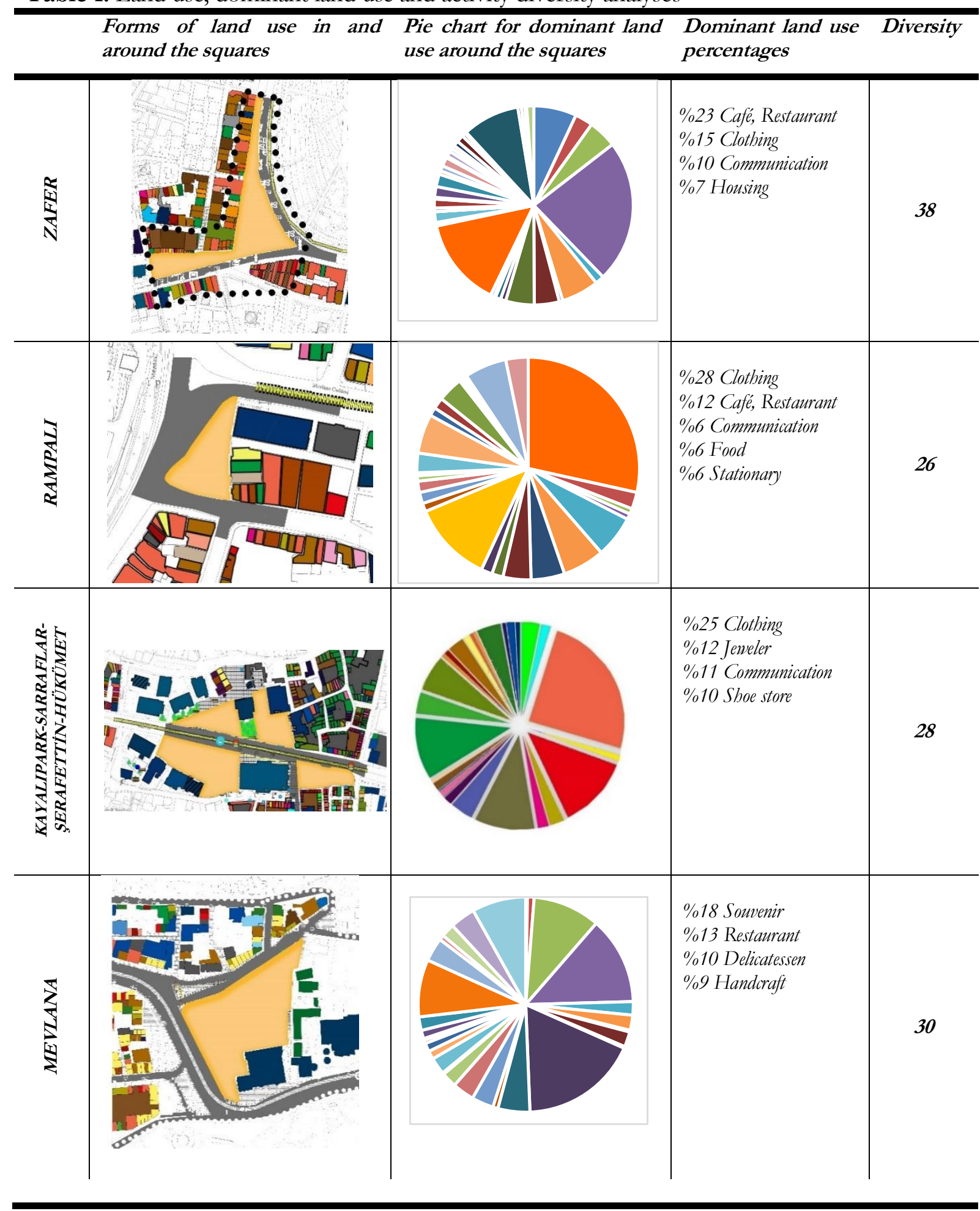

Land Use Findings; An analysis of the forms of land use and activity diversity around the squares, which determine the purpose of use of the squares, showed that functions of clothing, food and beverage, communication and stationary were dominant in Zafer and Rampalı squares, which are the centers of the city and trade. Since Kayalipark-Sarraflar-Şerafettin and Hükümet squares had an integrated functional relationship with one another, land use analyses were jointly conducted. The functions of clothing, jeweler and shoe store functions were found to mainly exist around these squares, which are located close to the Bedesten and Sarraflar bazaars and have strong 
Yılmaz Çakmak, B., Topçu, M., (2018). An evaluation of urban open spaces in Historical City Center of Konya in the context of pedestrian mobility.Journal of Human Sciences, 15(1), 1827-1846. doi:10.14687/jhs.v15i4.5506

functional relationships with these bazaars. Because of its relationship with the mausoleum, Mevlana Square mainly accommodates functions such as souvenir, restaurant and handcraft.

\section{C2. User Density and Preference}

In the study, pedestrian density counts were carried out at specified times of the day on weekdays and at the weekend in order to determine the usage density of the squares. The analyses performed are shown in Table 2.

Table 2. Table of pedestrian count for the usage density of squares, weekdays-weekend
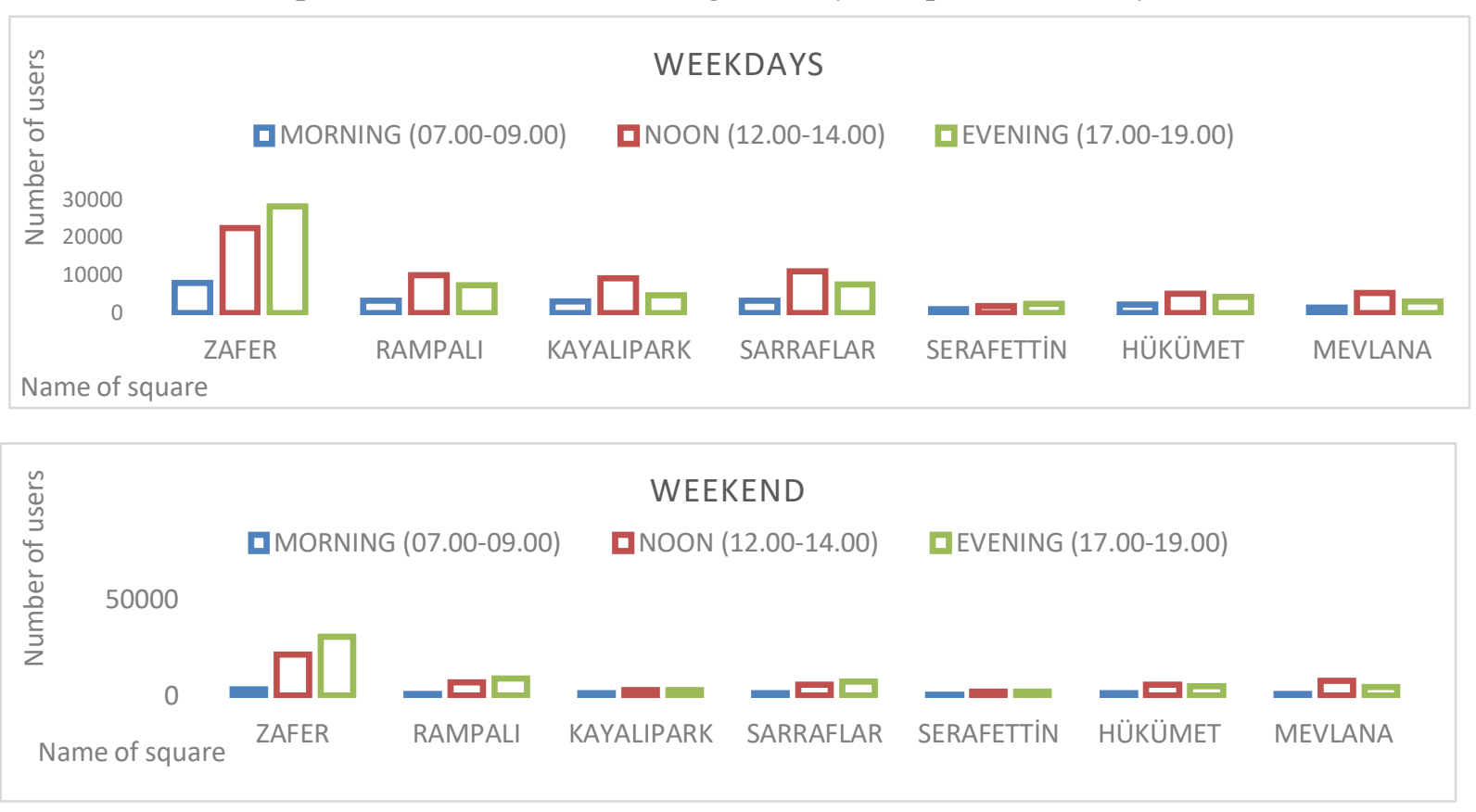

Table 3. Questionnaire results on the frequency of use of the squares, purpose and means of coming to the square and reason for preferring the square

\begin{tabular}{|c|c|c|c|c|c|}
\hline \multirow[t]{2}{*}{ Name of Square } & \multirow[t]{2}{*}{$\begin{array}{l}\text { Frequency of use } \\
\text { of the square }\end{array}$} & \multirow{2}{*}{$\begin{array}{c}\text { Purpose of } \\
\text { coming to the } \\
\text { square }\end{array}$} & \multicolumn{2}{|c|}{$\begin{array}{c}\text { Means of coming to } \\
\text { the square }\end{array}$} & \multirow[t]{2}{*}{$\begin{array}{c}\text { Reason for preferring } \\
\text { the square }\end{array}$} \\
\hline & & & Pedestrian & $\begin{array}{l}\text { Public } \\
\text { Transport }\end{array}$ & \\
\hline ZAFER & Very often $61 \%$ & relaxation $50 \%$ & $25 \%$ & $53 \%$ & $\begin{array}{l}\text { 25\% workplace, home } \\
\text {,dormitory }\end{array}$ \\
\hline RAMPALI & Very often $25 \%$ & relaxation $67 \%$ & $37 \%$ & $47 \%$ & $32 \%$ central and on the way \\
\hline KAYALIPARK & Very often $22 \%$ & relaxation $76 \%$ & $36 \%$ & $56 \%$ & $\begin{array}{l}30 \% \text { business } 30 \% \\
\text { relaxation }\end{array}$ \\
\hline SARRAFLAR & Very often $58 \%$ & relaxation $72 \%$ & $62 \%$ & $16 \%$ & $\begin{array}{l}32 \% \text { business } 36 \% \\
\text { shopping } 32 \% \text { relaxation }\end{array}$ \\
\hline ŞERAFETTİN & Very often $66 \%$ & relaxation $42 \%$ & $39 \%$ & $56 \%$ & $54 \%$ relaxation \\
\hline HÜKÜMET & Very often $22 \%$ & relaxation $70 \%$ & $32 \%$ & $30 \%$ & $24 \%$ business \\
\hline$M E V L A N A$ & Very often $27 \%$ & relaxation $40 \%$ & $41 \%$ & $16 \%$ & $40 \%$ to visit the mausoleum \\
\hline
\end{tabular}

Pedestrian count analysis: According to the conducted pedestrian counts, the busiest square at morning, noon and evening hours during weekdays and weekends was Zafer Square. Pedestrian densities of Rampalı, Kayalıpark and Sarraflar squares were also observed to increase on weekdays at noon hours. In addition, pedestrian density was also seen to increase at evening hours on weekdays and at weekends in Rampalı and Sarraflar squares. 
Yılmaz Çakmak, B., Topçu, M., (2018). An evaluation of urban open spaces in Historical City Center of Konya in the context of pedestrian mobility.Journal of Human Sciences, 15(1), 1827-1846. doi:10.14687/jhs.v15i4.5506

Questionnaire Study: The questionnaire study was conducted on 60 participants for each square. According to the questionnaire study conducted to analyze the pedestrians' frequency of use of the squares, their purpose of coming to the square, means of visiting the square and reason for preferring the square, it was determined that the most frequently used were Zafer, Sarraflar and Şerafettin squares.

It was found out that the squares were generally used for relaxation purposes and the users relaxed the most frequently in Kayalıpark and Sarraflar squares.

Regarding the means of coming to the square, it is seen that while Serafettin, Kayalıpark, Zafer and Rampalı squares were mainly accessed by public transport, pedestrian access was more frequent to the other squares.

When the reasons for preferring the squares were examined, it was seen that Kayalipark, Sarraflar and Şerafettin squares were the most preferred for relaxation, Zafer and Hükümet squares were preferred for business, Rampalı was preferred for being on the way and passing, and Mevlana was preferred for visiting the mausoleum.

\section{C3. Accessibility (Global-Historical Area), C4. Accessibility (Local-Close Environment)}

The criterion of accessibility was measured using the space syntax method. The space syntax method is a mathematical model used for discovering and comparing features such as natural mobility and density of use based on the examination of urban open spaces. By means of this method, it is possible to compare different urban spaces or urban spaces in different processes especially based on the phenomenon of mobility. The space syntax method, which examines and explains the relationships between urban spaces and buildings, was developed at "The Unit for Architectural Studies, University College London" (Hillier \& Hanson, 1984). This method reveals the integrated urban structure not based volumes, but by examining the open space where urban life occurs among these volumes. This method is supported with the concept of accessibility in terms of topological and geometric terminology (Hillier, 2007; Hillier \& Hanson, 1984; Oliveira, 2013). Syntactic maps are developed and statistical data are obtained based on an "axial map" consisting of the fewest and longest axes in the urban whole. The most important finding obtained through space syntax analysis on an axial map is "Integration value" and "Integration map". Through this map, the axes that are in line for the densest use or are currently used most within the system are instantly seen while the spaces that were isolated and out of use can also be seen.

An axial map was created for the area within the borders of the historical district of the city of Konya that comprises the squares to measure and compare the accessibility values of the squares. Integration values were calculated on the generated axial map by using Depthmap software (global $\mathrm{HH}$ and local $\mathrm{r} 3$ ) and integration maps were produced (Figures 5, 6). Afterwards, the accessibility among the squares whose integration values were selected as sample and the accessibility between these squares and the whole historical city center were mapped in detail and integration values were calculated (Table 4). 


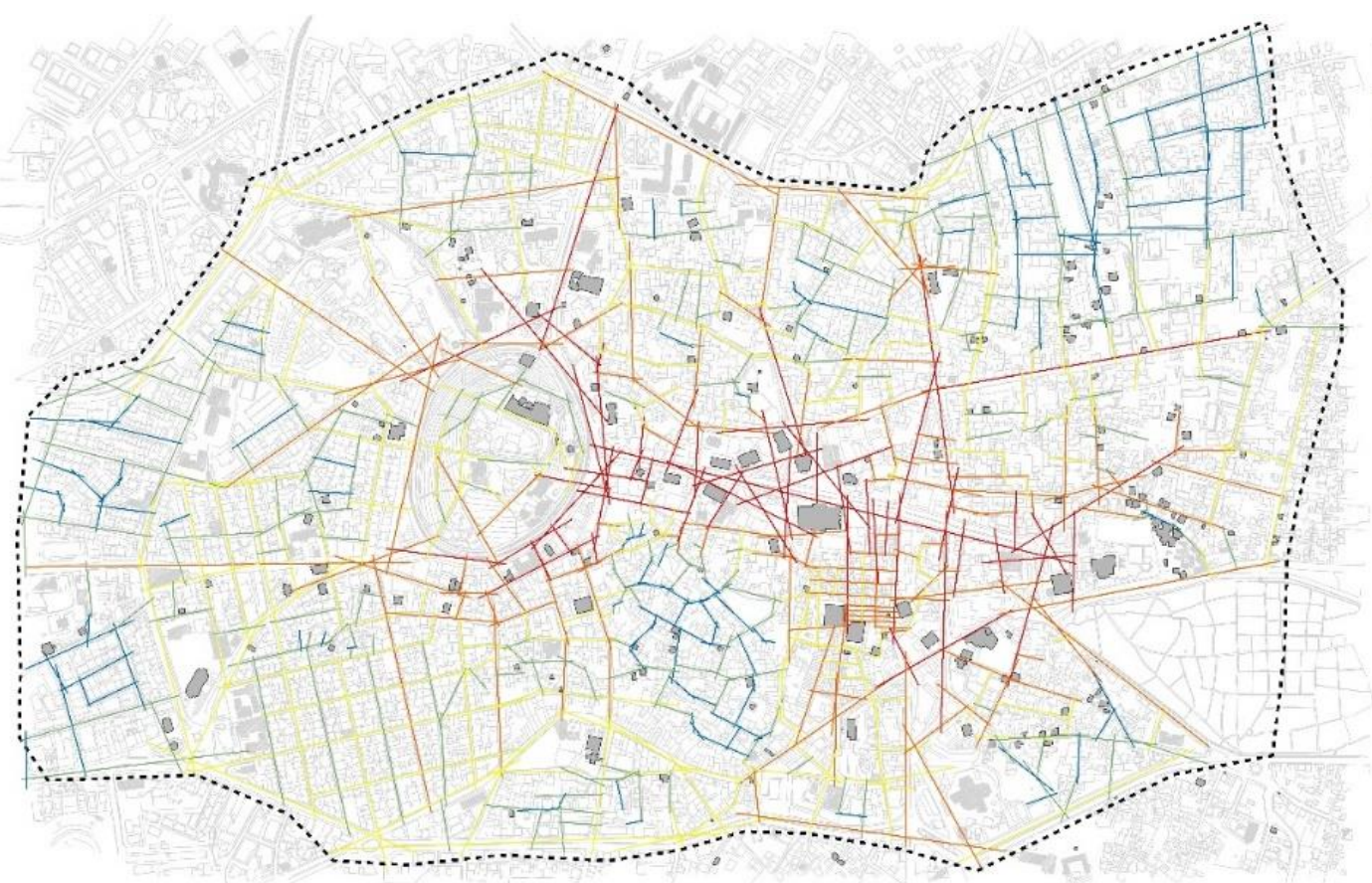

Integration Global HH

$0.754428-1.018711$

$1.018712-1.172811$

$1.172812-1.337202$

$1.337203-1.550127$

$1.550128-2.098959$

Figure 5. "Global" integration map of the historical district

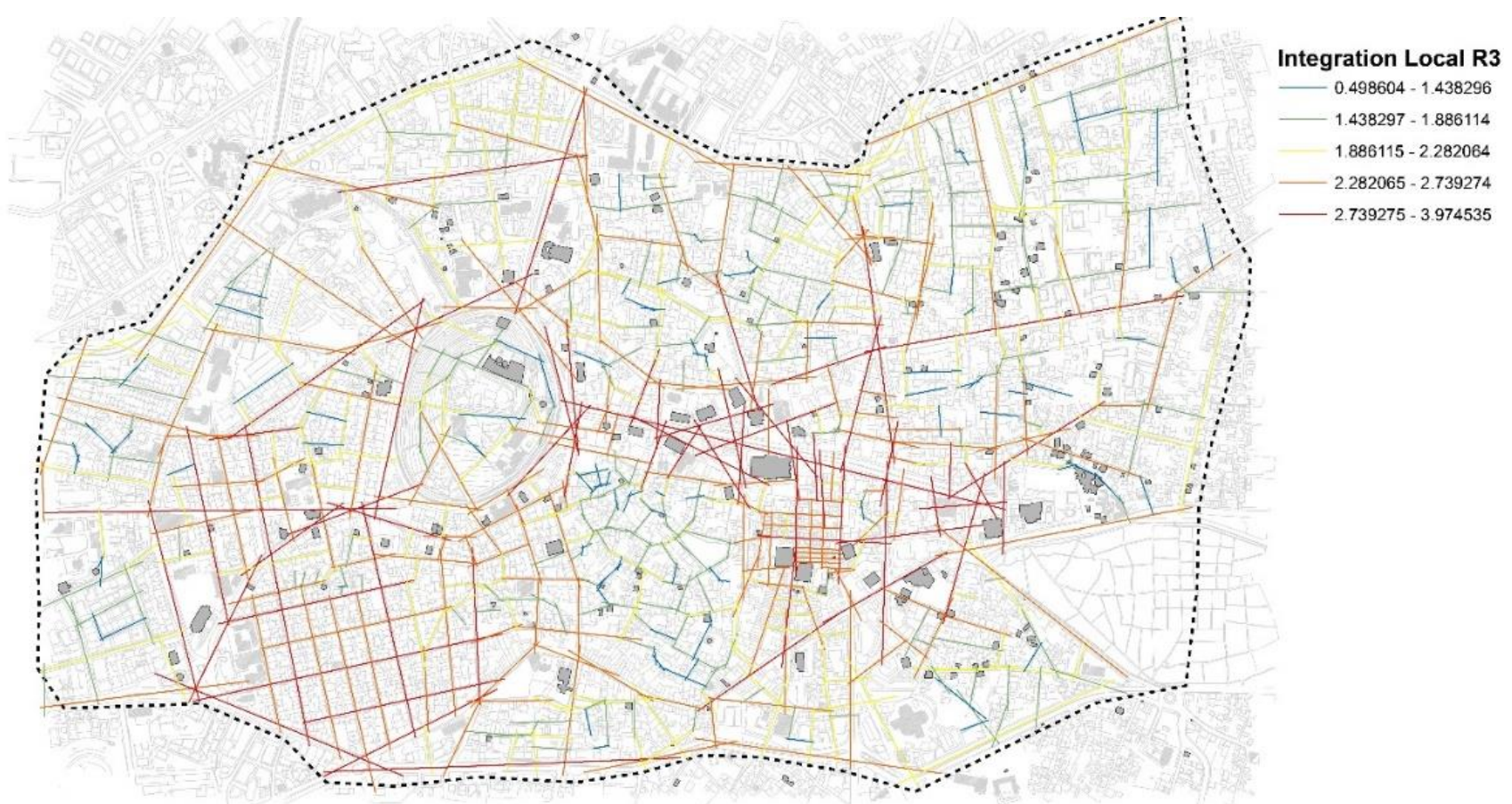

Figure 6. Local integration map of the historical district

Table 4. Mean global and local integration values for the squares selected as sample 
Yılmaz Çakmak, B., Topçu, M., (2018). An evaluation of urban open spaces in Historical City Center of Konya in the context of pedestrian mobility.Journal of Human Sciences, 15(1), 1827-1846. doi:10.14687/jhs.v15i4.5506

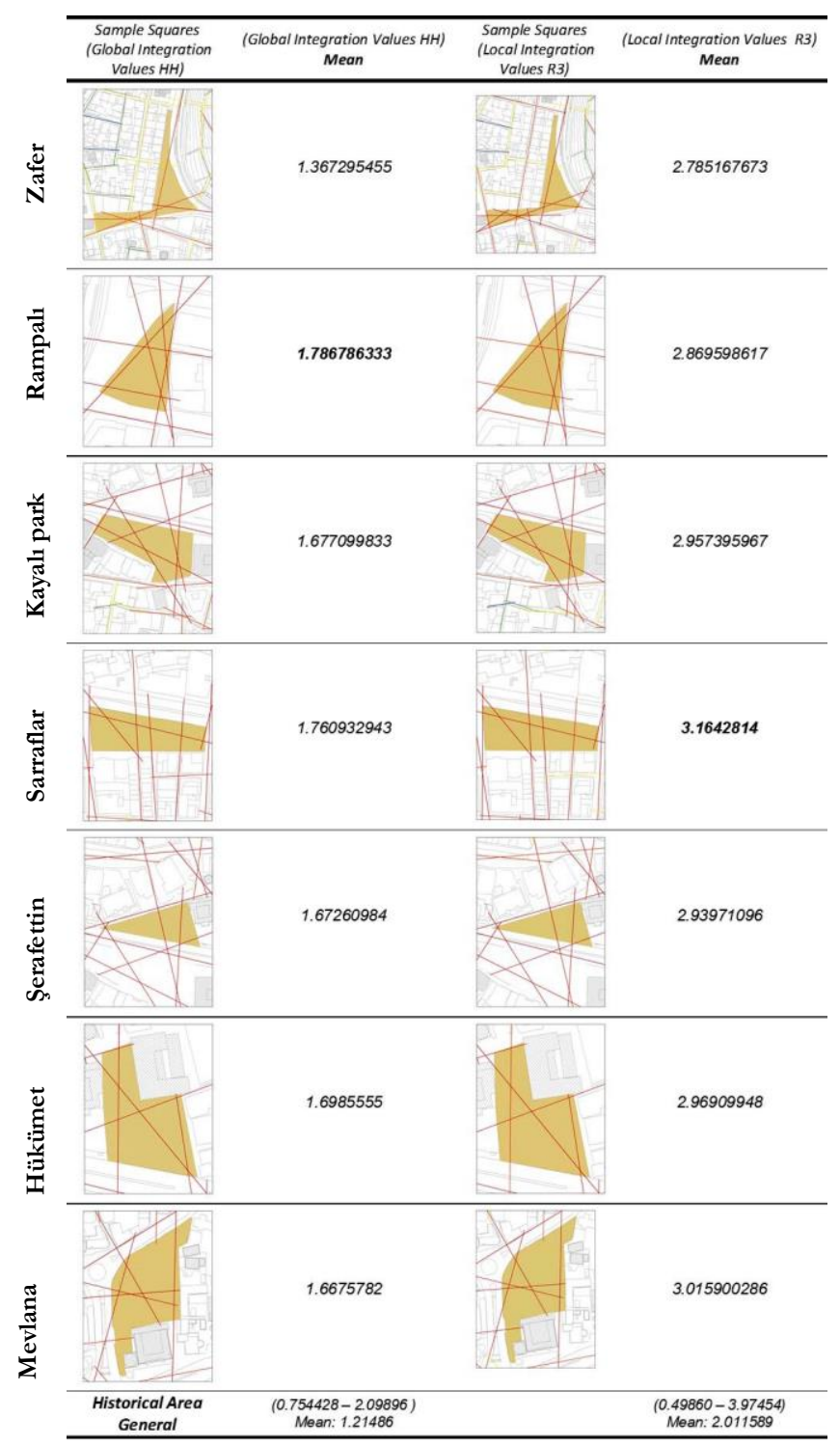

In the space syntax analysis conducted for accessibility, the global integration analysis of the historical district of Konya revealed that the integration values were between 0.75428 and 2.098959, and the mean global integration value was found to be 1.21486 (Figure xx). When we examine the mean global integration values of the squares (Zafer; 1.36729, Rampali; 1.78628, Kayalipark; 1.67709, Sarraflar; 1.76093, Șerafettin; 1.67260, Hükümet; 1.69855, Mevlana; 1.66757), we can see that the integration values for all the squares were higher than the mean value (Figure $\mathrm{xx}$ ). The comparison of the global accessibility of the squares showed that Rampalı and Sarraflar squares had the highest accessibility, whereas the Zafer square had the lowest accessibility.

The local integration analysis of the squares showed that the integration values in the historical district were between 0.498604 and 3.974535, and the mean local integration value was calculated as 2.011589. If we examine the mean local integration values of the squares (Zafer; 2.785167, Rampali; 2,869598, Kayalipark; 2.957395, Sarraflar; 3.164814, Serafettin; 2.939710, Hükeümet; 2.969099, Mevlana; 3.01590), we can see that the integration values of all the squares were higher than the mean value also at the local scale. When we compare the local accessibility of the squares, we see that Mevlana and Sarraflar were squares with the highest accessibility, whereas Zafer square had the lowest accessibility among the selected squares. 
Yılmaz Çakmak, B., Topçu, M., (2018). An evaluation of urban open spaces in Historical City Center of Konya in the context of pedestrian mobility.Journal of Human Sciences, 15(1), 1827-1846. doi:10.14687/jhs.v15i4.5506

As a general assessment, we can say that the accessibility of the squares other than Zafer Square was at levels close to each other and at high values, and interventions to increase the accessibility between Zafer square and other squares would result in a more sustainable relationship among the squares.

\section{C5. Shape-Aesthetics}

The geometric exploration of the city gives us some basic ideas. Different cities with similar geometries individually exhibit exclusive and unique characteristics. The conglomeration of roads and buildings serve to define the atmosphere of the space as in the three dimensional formation. Definition of the urban structure is connected to the definition of the basic fabric. This is very important for the intelligibility of the city. The squares in the urban fabric, communal spaces and the links that connect them are each a touchstone in this definition of identity (Cohen, 1999).

In urban open spaces, the shape-aesthetics analysis of the square is conducted by classifying the changes that occur in its basic geometry. In his book entitled Urban Space, Krier (1979) typologically classifies the alternatives for the regular and irregular change of the morphological structure of the square. This classification is categorized as angling, segment, addition, overlapping and distortion. The variation in basic geometry is classified in 3 main categories as the alteration of internal angles, alteration of external dimensions, and alteration of both internal angles and external dimensions (Figure 7).
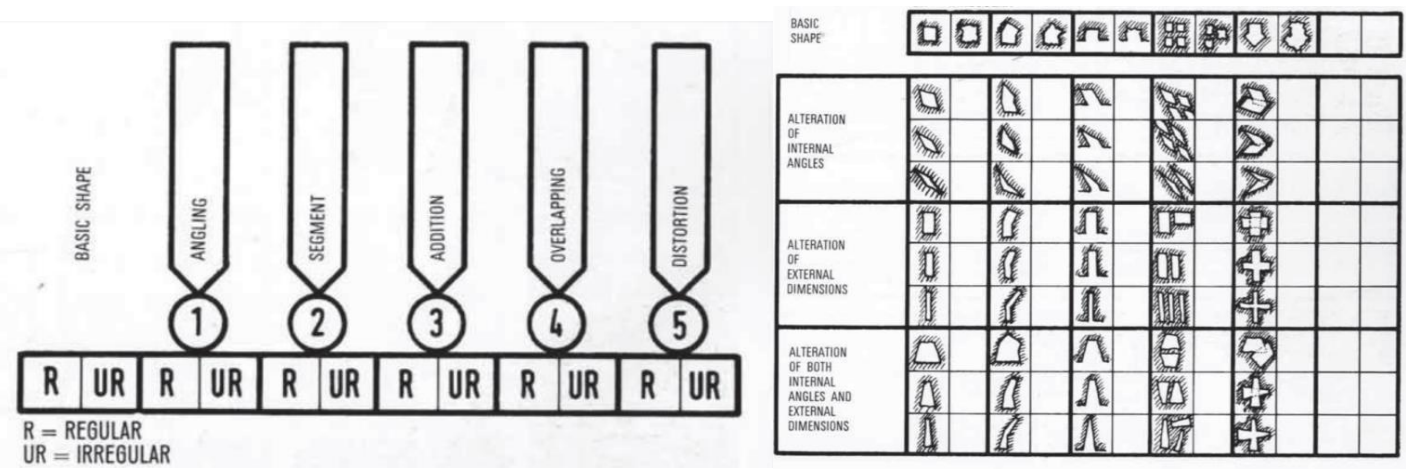

Figure 7. Concepts regarding basic form and the mode of change in form (Krier \& Rowe, 1979)

The formal geometries of the squares are defined based on Krier's classification criteria (Table 5). Qualities of the form of the square will be interpreted together with the other analyses and their relationship with use, preference and accessibility values will be evaluated (Table 6).

Table 5. Analysis criteria for the squares located in the study area

\begin{tabular}{ccc}
\hline BASIC FORM & STATE OF REGULARITY & STATE OF ALTERATION \\
\hline Angling & & alteration of internal angles \\
Segment & Regular & alteration of external dimensions \\
Addition & Irregular & alteration of both internal angles and \\
Overlapping & & external dimensions \\
Distortion &
\end{tabular}


Yılmaz Çakmak, B., Topçu, M., (2018). An evaluation of urban open spaces in Historical City Center of Konya in the context of pedestrian mobility.Journal of Human Sciences, 15(1), 1827-1846. doi:10.14687/jhs.v15i4.5506

Table 6. Form analysis of the squares located in the study area

Name and location of the square Geometry of the square Form, regularity and alteration

criteria

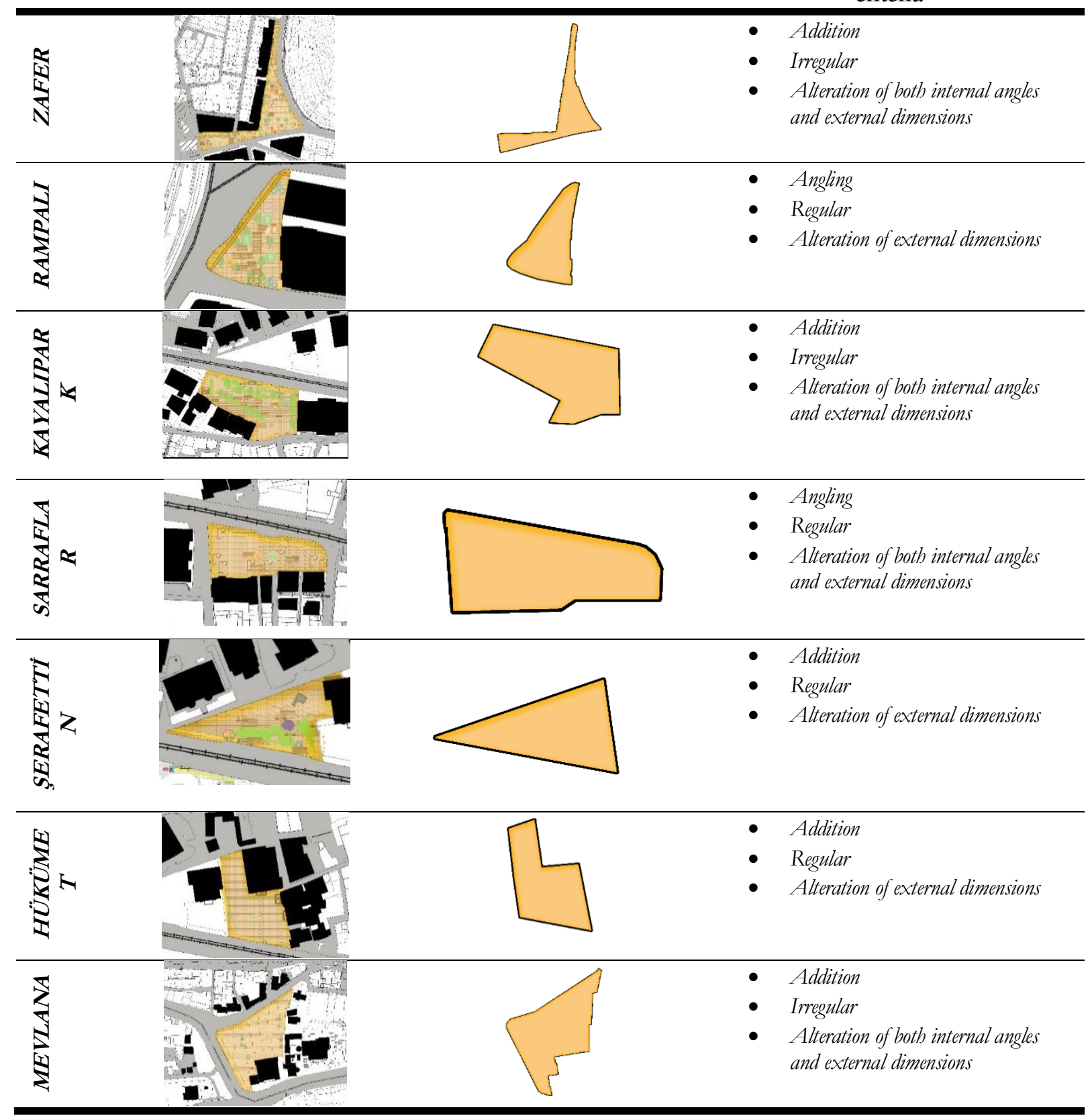

Shape-Aesthetics Analysis Results of the analyses on the geometric structures of the squares examined in the study showed that while Zafer, Kayalipark and Mevlana squares have irregular geometric forms, Hükümet, Şerafettin, Sarraflar and Rampalı squares have regular geometric forms. Sarraflar and Rampalı squares have angling, whereas the other squares have additional forms. In the light of the findings, it was determined that squares with regular forms similar to the basic geometry are more suitable in terms of urban space arrangement, accessibility, and user preference and behaviors.

\section{C6. Urban Open Space and C7. Perception}

An important concept in determining the quality of an urban open space is livability. Livability is a concept related to the presence of certain factors existing in a square such as urban furniture, lighting elements, quantity of green space and landscaping elements and the safe use of 
Yılmaz Çakmak, B., Topçu, M., (2018). An evaluation of urban open spaces in Historical City Center of Konya in the context of pedestrian mobility.Journal of Human Sciences, 15(1), 1827-1846. doi:10.14687/jhs.v15i4.5506

these elements. The urban furniture and arrangements sought in the squares for the study are presented below.

Table 7. Criteria Sought in Urban Open Space Analysis

\begin{tabular}{llll}
\hline \multicolumn{4}{c}{ Criteria Sought in Urban Open Space Analysis } \\
\hline Green fabric & Ground/square clock & Charging pole & Stone paved road \\
Traffic lights & Lamp post & W.C. & keystone road \\
ATMs & Sitting element & Fountain & Sidewalk \\
Barrier & Hut & Bus stops & Tramway road \\
Electric transformer & Billboard & Bicycle parking areas & Car park \\
Flower tubs & Phone box & Pool & Tramway stop \\
Waste bins & Fireplug & Asphalt road & \\
Recycling bins & Signboard & Guide track & \\
\hline
\end{tabular}

The equipment and applications existing in the spaces were determined within the scope of the urban open space analysis. Urban open space analyses conducted for each square showed that urban furniture, shade elements and functional equipment were effective in the pedestrians' frequency of use and preferences.

The obtained data were identified on maps through urban open space analyses and adequacy levels were specified. The results of the analysis for these values and the states of adequacy are presented in Table 8.

Table 8. Urban open space value analyses

\begin{tabular}{|c|c|c|c|}
\hline $\begin{array}{c}\text { URBAN OPEN SPACE } \\
\text { ANALYSIS }\end{array}$ & VISUAL OF THE SPACE & \multicolumn{2}{|c|}{ CRITERIA } \\
\hline$\frac{\pi}{N}$ & 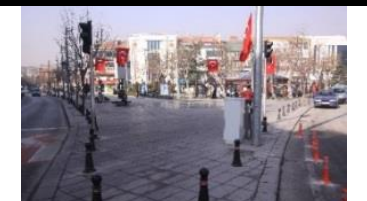 & $\begin{array}{l}\text { Urban furniture } \\
\text { Lighting } \\
\text { Signs } \\
\text { Flower tubs } \\
\text { Pool } \\
\text { Stop } \\
\text { Carpark }\end{array}$ & $\begin{array}{l}\text { Adequate } \\
\text { available } \\
\text { available } \\
\text { not available } \\
\text { not available not } \\
\text { available } \\
\text { avalable } \\
\text { not avalable }\end{array}$ \\
\hline 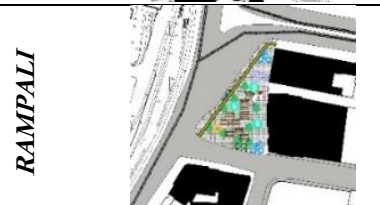 & & $\begin{array}{l}\text { Urban furniture } \\
\text { Lighting } \\
\text { Signs } \\
\text { Flower tubs } \\
\text { Pool } \\
\text { Stop } \\
\text { Car park }\end{array}$ & $\begin{array}{l}\text { Inadequate } \\
\text { available } \\
\text { available } \\
\text { not available not } \\
\text { avaiable } \\
\text { not available } \\
\text { avalable } \\
\text { not available }\end{array}$ \\
\hline$\frac{1}{3}$ & & $\begin{array}{l}\text { Urban furniture } \\
\text { Lighting } \\
\text { Signs } \\
\text { Flower tubs } \\
\text { Pool } \\
\text { Stop } \\
\text { Carpark }\end{array}$ & $\begin{array}{l}\begin{array}{l}\text { Adequate } \\
\text { available } \\
\text { avaiblele } \\
\text { not avalable } \\
\text { available } \\
\text { avaiable } \\
\text { avalable } \\
\text { notavalable }\end{array}\end{array}$ \\
\hline 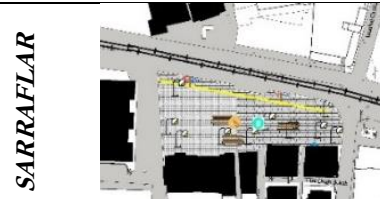 & & $\begin{array}{l}\text { Urban furniture } \\
\text { Lighting } \\
\text { Signs } \\
\text { Flower tubs } \\
\text { Pool } \\
\text { Stop } \\
\text { Carpark }\end{array}$ & 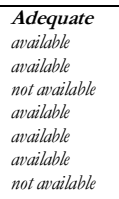 \\
\hline 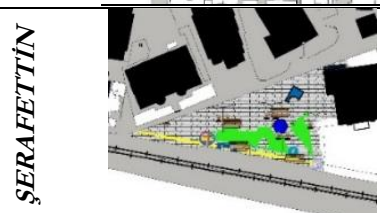 & $m$ & $\begin{array}{l}\text { Urban furniture } \\
\text { Lighting } \\
\text { Signs } \\
\text { Flower tubs } \\
\text { Pool } \\
\text { Stop } \\
\text { Carpark }\end{array}$ & 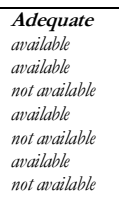 \\
\hline
\end{tabular}


Yılmaz Çakmak, B., Topçu, M., (2018). An evaluation of urban open spaces in Historical City Center of Konya in the context of pedestrian mobility.Journal of Human Sciences, 15(1), 1827-1846. doi:10.14687/ihs.v15i4.5506

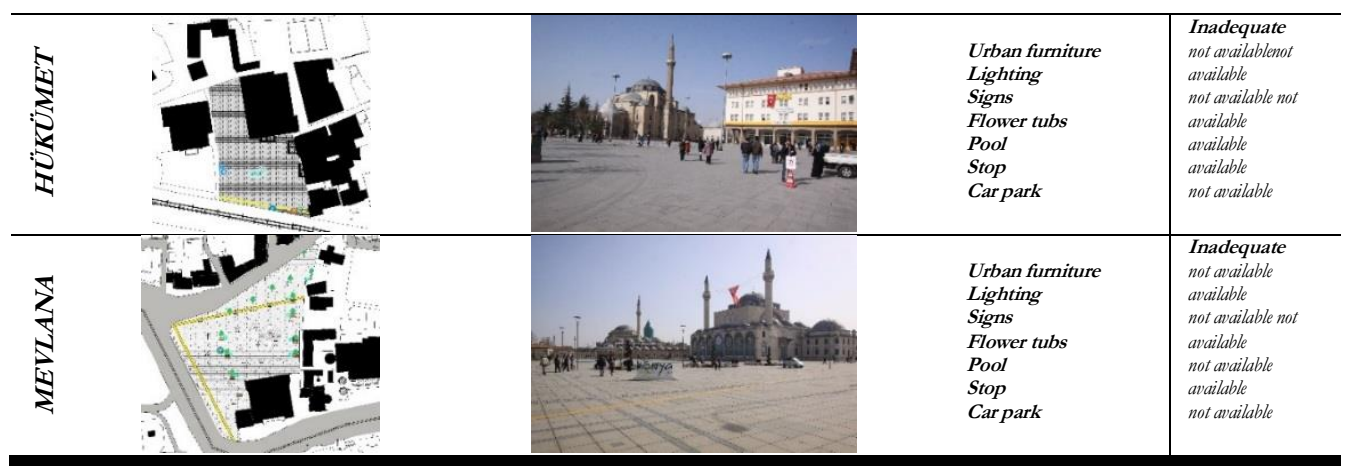

In addition, the cultural and historical identity of the squares also affects pedestrian use and preferences. For this purpose, the cultural and historical landmarks that the squares possess were evaluated through visuals and a questionnaire study. In the questionnaire study, questions regarding the semantic value of the squares were asked to 60 participants for each square and the results shown in Table 9 were achieved through the categorization of the responses.

Table 9: Table of values representing the place of squares in the memory

\begin{tabular}{|c|c|c|}
\hline VISUAL OF THE SPACE & $\begin{array}{l}\text { CULTURAL- } \\
\text { HISTORICAL } \\
\text { LANDMARKS }\end{array}$ & $\begin{array}{c}\text { SPACE FEATURE/ } \\
\text { PLACE IN THE } \\
\text { MEMORY }\end{array}$ \\
\hline N & & $\begin{array}{l}\text { Sundial } \\
\text { Alaaddin Hill } \\
\text { Camh Kösk } \\
\text { Zafer Tramway stop }\end{array}$ \\
\hline 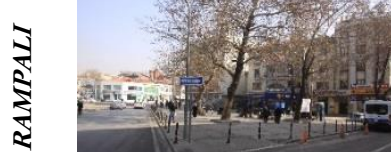 & & $\begin{array}{l}\text { Alaaddin Hill } \\
\text { Rampah Carşı } \\
\text { Zafer Tramway stop } \\
\dot{I}_{S} \text { Bank Building }\end{array}$ \\
\hline ปับ & & $\begin{array}{l}\text { Stone element and pool } \\
\text { Bus stop } \\
\text { Ziraat Bank Building } \\
\text { Government House } \\
\text { İplikgi Mosque }\end{array}$ \\
\hline क्रे & & $\begin{array}{l}\text { Sarraflar underground market } \\
\text { Government House } \\
\text { Statue } \\
\text { Pool }\end{array}$ \\
\hline$\sum_{\substack{1 \\
2}}^{3}$ & & $\begin{array}{l}\text { Serafettin Mosque } \\
\text { Old Industrial School Building } \\
\text { Government House }\end{array}$ \\
\hline$\frac{\sqrt{2}}{\sqrt[3]{2}}$ & & $\begin{array}{l}\text { Pool } \\
\text { Pigeons } \\
\text { Serafeettin Mosque } \\
\text { Yapt Kredi Bank Building }\end{array}$ \\
\hline
\end{tabular}


Yılmaz Çakmak, B., Topçu, M., (2018). An evaluation of urban open spaces in Historical City Center of Konya in the context of pedestrian mobility.Journal of Human Sciences, 15(1), 1827-1846. doi:10.14687/jhs.v15i4.5506

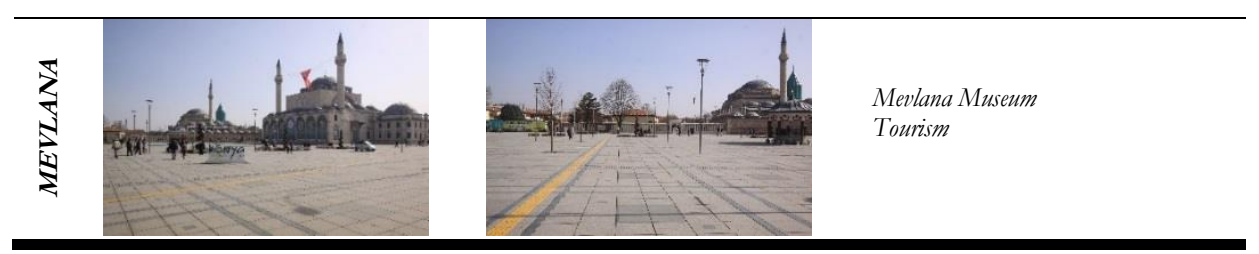

Urban Open Space Analysis and Cultural-Historical Analysis: Considering the pedestrians' preferences and diversity of functional use for the adequacy of urban equipment and arrangements, the urban open space analysis showed that Zafer and Kayalıpark squares had an adequate level of equipment and arrangements, whereas the other squares could not sufficiently meet the needs of the users. Şerafettin and Mevlana squares were insufficient in terms of urban equipment serving the function of shaded sitting and relaxation, the former for being located on a transit route, and the latter for being a square used by pedestrians for visiting and passing by on their way.

In terms of the symbolic elements and semantic value that the squares possess, Zafer square with the sundial, Kayalipark square with the stone-shaped pool, and Hükümet square with pigeons and pool, hold a place in the memories in terms of semantic value. It is seen that Rampalı Square is remembered for the Rampalı Çarşı on its side, Şerafettin Square for the Şerafettin Mosque, and Mevlana Square for the Mevlana Museum and the powerful historical structure nearby adds meaning and memory value to the square.

When examined from this point of view, it is seen that the structures with strong symbolic value and high semantic value located in the historical city center add value to the squares nearby in terms of name, memory, and also in urban direction finding.

\section{Conclusion}

In the study, continuity and sustainability of squares is evaluated in the context of the concepts of function diversity, accessibility-form and livability-identity and specific to selected squares. In addition, suggestions are offered regarding the concept in terms of which the squares selected as sample should be improved to maintain the continuity among the squares and to achieve a more integrated pedestrian mobility in the historical district. The findings regarding the squares obtained within the scope of the 7 criteria of the study are summarized in Table 10.

Table 10: Findings obtained in line with the method of the study

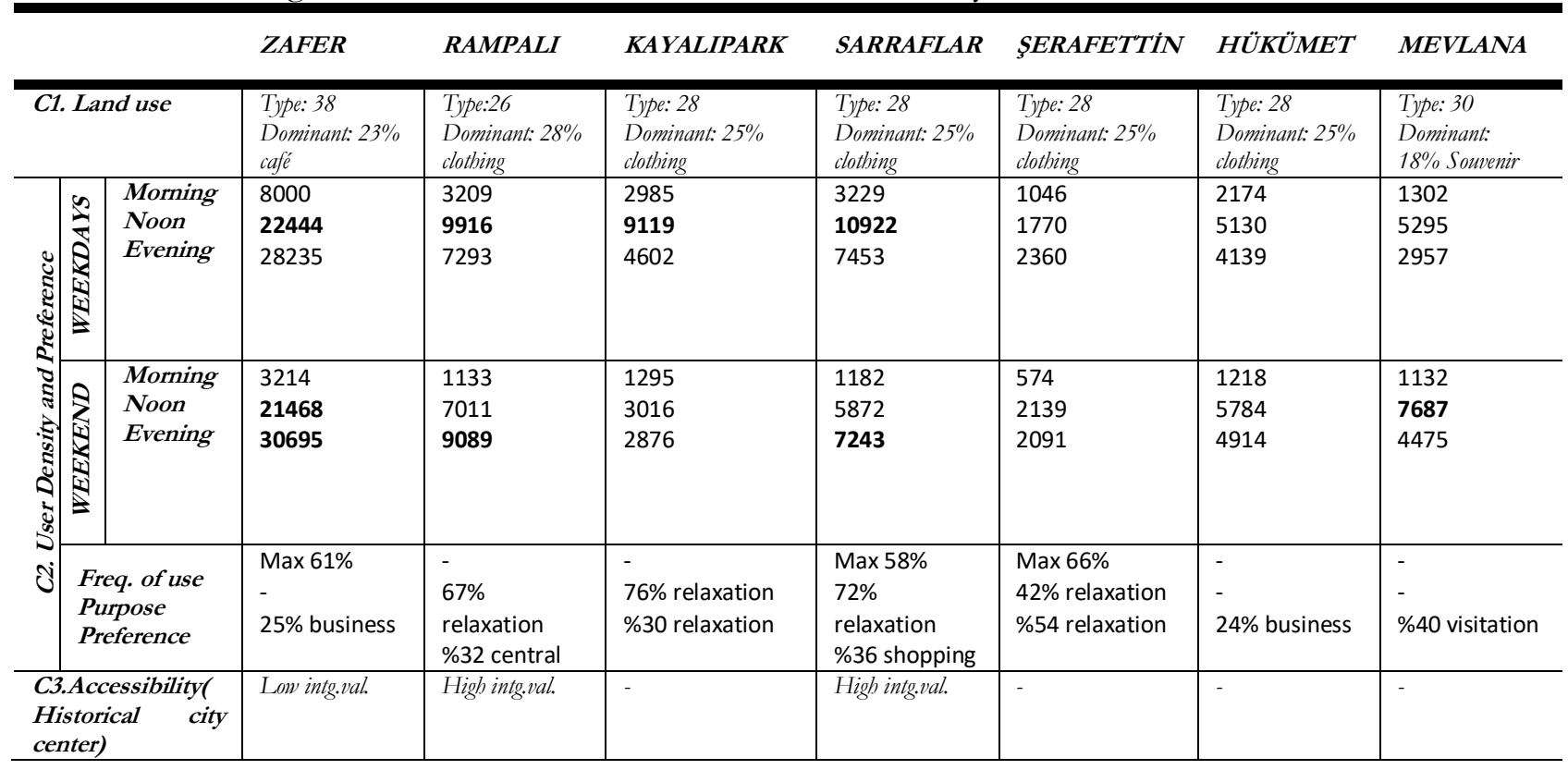


Yılmaz Çakmak, B., Topçu, M., (2018). An evaluation of urban open spaces in Historical City Center of Konya in the context of pedestrian mobility.Journal of Human Sciences, 15(1), 1827-1846. doi:10.14687/jhs.v15i4.5506

\begin{tabular}{l|l|l|l|l|l|l|l}
\hline $\begin{array}{l}\text { C4.Accessibility( } \\
\begin{array}{l}\text { Close } \\
\text { environment) }\end{array}\end{array}$ & Low intg.val. & - & - & High intg.val. & - & High intg.val. \\
\hline $\begin{array}{l}\text { C5. Shape- } \\
\text { Aesthetics }\end{array}$ & Irregular & Regular & Irregular & Regular & Regular & Regular \\
\hline $\begin{array}{l}\text { C6.Urban Open } \\
\text { Space }\end{array}$ & Adequate & Inadequate & Adequate & Inadequate & Adequate & Inadequate & Inadequate \\
\hline $\begin{array}{l}\text { C7. Perception } \\
\text { Sun clock }\end{array}$ & $\begin{array}{l}\text { Rampale old } \\
\text { book store }\end{array}$ & Rock pool & $\begin{array}{l}\text { Underground } \\
\text { Jemeler market }\end{array}$ & Serafettin Mosque & $\begin{array}{l}\text { Government } \\
\text { House }\end{array}$ & $\begin{array}{l}\text { Mevlana } \\
\text { Museum }\end{array}$ \\
\hline
\end{tabular}

Zafer Square has an irregular and articulated geometric form, which is different from the basic geometry. In this context, it is perceived as two separate areas and creates a weak perception in terms of spatial integrity. Regarding urban open space analysis, it is seen that the existing urban furniture is adequate and provides a suitable environment to the users of the square in terms of quality of livability. Among all the squares, Zafer square is the one with the lowest local and global accessibility values. In terms of land use, it is the square where dominant functions center upon food and beverage and which has the $2^{\text {nd }}$ highest frequency of use with a rate of $66 \%$. It accommodates 38 different types of functions. The users' reason for preferring the square was determined as business-shopping and education with a rate of $25 \%$. When we associate function diversity and preference of use with pedestrian counts, we see that Zafer square has on average two times more pedestrian use compared to other squares. The urban landmarks present in the square are sundial, Camlı Kössk and Zafer Tramway Stop.

For maintaining the continuity of Zafer square with all the other squares, the perception of geometric arrangement as two different squares and the arrangement of the urban furniture in this way would increase the use of the square. Another suggestion is related to the urban transformation works to be conducted in the historical district. The design of open spaces that will increase the spatial integration between Zafer square and Mevlana square will also increase the low level of integration of Zafer square. This could be possible through forming a new open space on the axis between Rampalı Square and Zafer Square. In this way, connection will become shorter, the number of fragmented axes will decrease, and the level of relationship will increase.

Rampale Square has a regular triangular form in geometric terms, yet the urban equipment it holds is inadequate. Its central and accessible location increases the frequency of use and serves as the reason for preference. Rampalı Square has higher global accessibility compared to Zafer Square. While the dominant functions are on clothing, the square is mostly used for relaxation with a rate of $67 \%$. The users stated their reason for preferring the square as being located on a transit route and having a central location with a rate of $37 \%$. The urban landmarks existing in the square are Rampalı Çarşı and Alaaddin Hill. Improving the urban furniture and ground arrangements and increasing the function diversity, which is currently 26 , will be adequate for the continuity of Rampalı Square with the all the other squares.

Although Kayalpark Square has a form close to the basic geometry, its added form affects the perceptual organization of the square. In this sense, it has an irregular geometric form. Urban equipment is at an adequate level and this maintains the preference and frequency of use of the square. The dominant function in the square is clothing. The number of functions in the area is 28 , which is the smallest among all the squares. The urban landmarks in the square are the stone pool located in the middle and the bus stops. Increasing the diversity will increase the use and the users' preference of the square, and hence continuity.

Sarraflar Square has a regular geometric form, and this positively affects the perception of the square. Although urban equipment was found to be adequate, the number of shade elements should be increased. The square has high global and local accessibility. Pedestrian density was observed to increase especially during evening and noon hours. The square has the $3^{\text {rd }}$ highest frequency of use with a rate of $58 \%$. The users stated that they preferred the square for relaxing before and after shopping with a rate of $72 \%$. Jeweler and clothes shops are dominant in terms of land use and function. 
Yllmaz Çakmak, B., Topçu, M., (2018). An evaluation of urban open spaces in Historical City Center of Konya in the context of pedestrian mobility.Journal of Human Sciences, 15(1), 1827-1846. doi:10.14687/jhs.v15i4.5506

Serafettin Square is perceived to have a form which is both angled and regular in terms of geometric form. The square is adequate in terms of urban equipment and landscaping. Pedestrian density was observed to increase especially at evening and noon hours. The square has the highest frequency of use with a rate of $66 \%$. The most stated purpose of use was relaxation with a rate of $42 \%$. In terms of urban landmarks, it is in a location among the Old Industrial School, Şerafettin Mosque and the Government House, surrounded by historical buildings. We can say that the square has a positive status in terms of continuity among the squares.

Hükümet Square exhibits a regular form in terms of geometry. The insufficiency of urban equipment can be understood from the results of the conducted analyses. Pedestrian mobility in the square was observed to increase at noon and evening hours. When evaluated in terms of spatial accessibility, global and local integration values are above the average and high. This shows that the square has a good level of accessibility within the spatial construct. It is the square with the lowest frequency of use with a rate of $22 \%$. It was found out that the users preferred the square as a transit route to get to work at a rate of $24 \%$.

It is considered that improving the urban furniture and ground arrangements of the Hükümet square and increasing the functional diversity in the immediate surroundings will help to increase the period and frequency of use of the space. This will have a positive effect on the continuity of Hükümet square with all the other squares.

Mevlana Square has an irregular and articulated geometric form, which is different from the basic geometry. Despite its articulated form, it has a high level of perception because of being close to basic geometry. When examined in terms of urban open space analysis, it is seen that the existing urban furniture is inadequate and does not provide a suitable environment to the users of the square in terms of quality of livability. The square has high global and local spatial accessibility. Pedestrian density was observed to increase especially at noon hours. It has a low frequency of use with a rate of $27 \%$. It is understood to have a high rate of use for the purpose of relaxation with $40 \%$. In terms of functional diversity, souvenir and food and beverage are dominant functions with rates of $18 \%$ and $11 \%$, respectively. It was found out that the users come to the square for visiting the historical space (mausoleum).

As in the case of Hükümet Square, improving the urban furniture and ground arrangements of the Mevlana Square and increasing the functional diversity in the immediate surroundings are also considered to provide an increase in the period and frequency of use of the space. When considered in terms of the continuity among all of the squares, Mevlana and Zafer squares also have the characteristics of being the starting and ending points for the squares in the historical district for being located at the two extremes of the area.

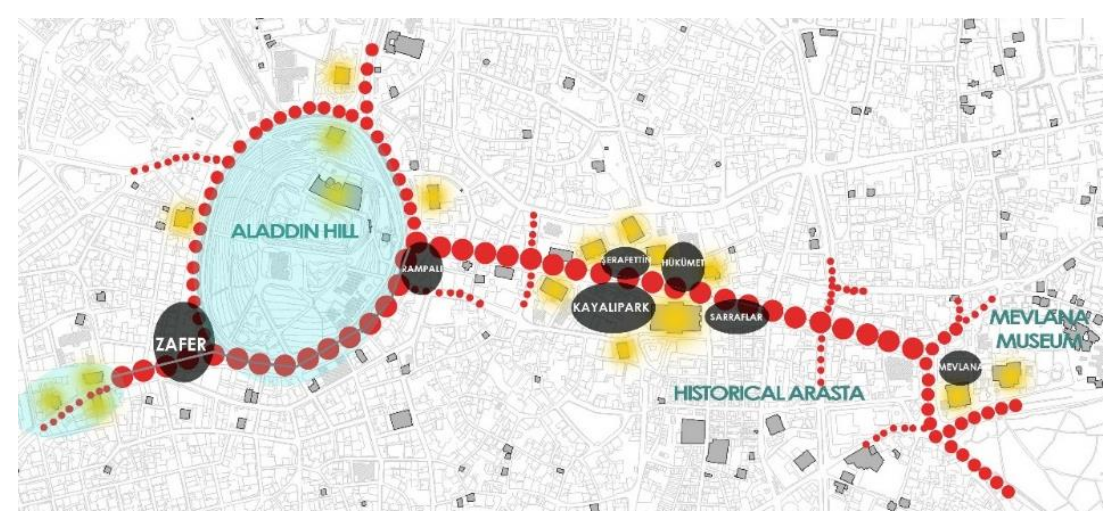

Figure 8. Squares and their relationships in the historical city center

In conclusion, for the perception of the 7 squares located in the historical city center within urban integrity and continuity, it is necessary to protect and improve the strong axis that connects these squares to one another. In this context, the $1^{\text {st }}$ axis which passes around Alaaddin Hill needs 
Yılmaz Çakmak, B., Topçu, M., (2018). An evaluation of urban open spaces in Historical City Center of Konya in the context of pedestrian mobility.Journal of Human Sciences, 15(1), 1827-1846. doi:10.14687/jhs.v15i4.5506

to be strengthened and its connection with the $2^{\text {nd }}$ axis should be reinforced. This connection will get stronger with a new square that will be designed between Zafer and Rampalı squares. The close locations of Kayalıpark, Sarraflar, Şerafettin and Hükümet squares cause them to be perceived as a single square and weaken their effects. It is also possible to maintain the continuity and protect the unique quality of these squares by means of urban equipment and functional differentiation. Despite its strong effect and semantic value, Mevlana square is inadequate in terms of urban equipment. The enrichment of its functions and improvement of the equipment and materials will enable this square to have an effective part in the continuity of the historical and touristic axis.

It is possible for the historical city center of Konya to be an effective component of urban identity only through the continuity of urban open spaces. The reinforcement of the relationship among the squares, which is defined in this study and needs to occur, and the contribution of this relationship to urban identity will be realized through the suggested arrangements. In this way, squares will be enabled to become a setting where urban identity is visible and the spirit of belonging to the place is felt, rather than being a space of passage.

\section{References}

Akkar Ercen, M., \& Belge, Z. S. (2017). Daha Yaşanabilir Kentler İçin Mikro Ölçek Bir Yürünebilirlik Modeli. METU Journal of the Faculty of Architecture, 34(1).

Ching, F. D. (2014). Architecture: Form, space, and order: John Wiley \& Sons.

Cohen, N. (1999). Urban conservation: The MIT Press.

Cullen, G. (1961). The concise townscape: London: Architectural Press.

Çubuk, M. (1991). Kamu Mekanları ve Kentsel Tasarım. Kamu Mekanlar Tasarmı ve Kent Mobilyalar Sempozуити, 15-16.

Erdönmez, M. E., \& Apak, H. (2015). Kentsel Bellekte Meydan San Marco Meydanı. Kent Akademisi, 8(3), 73-96.

Eren, İ. Ö. (2006). Kentsel Sürdürülebilirlik Bağlamında Bir İrdeleme: Üsküdar Meydanı. tasarm+ kuram dergisi, 10(18).

Francis, M. (1987). Urban Open Spaces, Advances in Environment, Behavior, and Design: New York, Plenum Press.

Giritlioglu, C. (1991). Sehirsel Mekan Ögeleri ve Tasarimi. ITÜ Mimarlik Fakültesi Yayini, Istanbul.

Hillier, B. (2007). Space is the machine: a configurational theory of architecture: Space Syntax.

Hillier, B., \& Hanson, J. (1984). The social logic of space, 1984. Cambridge: Press syndicate of the University of Cambridge.

Kılıç, A. (2001). Kentsel Aģık, Alanlarm Kullamıılar Tarafindan Değerlendirilmesi: Kadıköy İskele Meydam Ve Yakın Cevresi. Fen Bilimleri Enstitüsü.

Korkmaz, E. (2001). Kentsel Açık Alanlarn Kullamuclar Tarafindan Değerlendirilmesi: Beşiktaș Örneği. Fen Bilimleri Enstitüsü.

Krier, R., \& Rowe, C. (1979). Urban space: Academy editions London.

Kürkçüoğlu, E. (2015). Kentsel Dokuda Yaya Hareketlerinin Mekânsal ve Psikolojik. Etki Değerlendirmesi, Doktora Teri, İstanbul Teknik Üniversitesi Fen Bilimleri Enstitïsü

Kürkçüoğlu, E. \& Ocakçı, M. (2015). Kentsel Dokuda Mekânsal Yönelme Üzerine Bir Alg1-Davranış Çalışması: Kadıköy Çarşı Bölgesi, Megaron, 10(3), 365-388.

Lynch, K. (1960). The image of the city (Vol. 11): MIT press.

Norberg-Schulz, C. (1971). Existence, space \& architecture: New York: Praeger.

Oliveira, V. (2013). Morpho: a methodology for assessing urban form. Urban Morphology, 17(1), 21-33.

Özer, M. N., \& Ayten, M. A. (2005). Kamusal odak olarak kent meydanları. Şehir Plancilar Odas Planlama Dergisi, 3, 96-103.

Southworth, M. (1989). Theory and practice of contemporary urban design: a review of urban design plans in the United States. Town Planning Review, 60(4), 369.

Zorlu, F. (2008). Kentsel Doku-Ulaşım Sistemi İlisskileri. METU Journal of the Faculty of Architecture, 25(1).

URL 1: (http://www.superaktif.net/gezi/konya-alaaddin-tepesi) access date: 17.06.2018 